DOI 10.14746/ssp.2018.1.10

\author{
Krzysztof KaSIANIUK
}

Collegium Civitas w Warszawie

\title{
Czas w demokratycznym systemie parlamentarnym. Przypadek Sejmu RP w latach 1989-2015
}

Streszczenie: Niezależnie od perspektywy teoretycznej, aspekt czasu jest odnotowywany właściwie w każdym studium dotyczącym ewolucji systemów politycznych. Ma on szczególne znaczenie w analizach systemów przechodzących od autorytaryzmu do demokracji. Dotyczy to wielu systemów parlamentarnych, tj. opartych na mechanizmach periodycznych wyborów do ciał przedstawicielskich. Jednak stosunkowo mało uwagi poświęca się zagadnieniu czasu w polskiej literaturze politologicznej.

Celem artykułu jest prezentacja wyników badań nad wykorzystaniem czasu w polskim Sejmie w latach 1989-2015, tj. w kadencjach X-VII. Czas był analizowany w sensie fizycznym i organizacyjnym. Na podstawie oficjalnych danych Sejmu RP zbadano dynamikę wykorzystania czasu m.in. poprzez analizę liczby dni obrad i długości posiedzeń. Wyniki badań wskazują, że cechą charakterystyczną badanego okresu jest zmienna dynamika wykorzystania czasu w Sejmie. Ważny wydaje się w tym przypadku zwłaszcza okres między IV i V kadencją.

Słowa kluczowe: system polityczny, demokracja, Sejm RP, czas, transformacja systemowa

\section{Wprowadzenie}

Do truizmów życia codziennego należy stwierdzenie, że wszystko ma swój czas i swoje miejsce. Jednak w systemach demokratycznych przytoczone stwierdzenie nabiera szczególnego znaczenia. Cechą demokracji jest przecież jej periodyczność. Jeżeli działania i decyzje organów władzy państwowej mają uzyskiwać demokratyczną legitymizację, systematycznie powinny odbywać się powszechne wybory, w których obsadzane będą urzędy publiczne. Dzieje się tak dlatego, że w wyniku wyborów konkretne osoby i grupy uzyskują prawo do podejmowania decyzji w imieniu i - w sensie postulatywnym - na rzecz członków wspólnoty politycznej. Co kilka lat powinna zatem odbywać się ocena działalności niegdyś wybranych osób, która to z kolei ocena powinna obejmować m.in. stwierdzenie, czy czas przeznaczony na podejmowanie decyzji był 
wykorzystany właściwie. Oczywiście, owo „właściwie” może odnosić się do różnych wymiarów działania politycznego: od zakresu skuteczności realizacji postulatów politycznych do jakości podejmowanych prób realizacji podnoszonych postulatów.

Generalnie jednak procedura demokratyczna jest formą rozliczenia decydentów z ich działań (Sartori, 1994; Schumpeter, 2013), zaś periodyczność wyborów pozwala m.in. na systematyczną akomodację interesów oraz względnie uporządkowaną ewolucję systemu politycznego (Easton, 1979, s. 17). Dotyczy to zwłaszcza systemów przechodzących przez proces transformacji - gospodarczej, społecznej i politycznej. W systemie przechodzącym transformację czas stanowi niekiedy ramę, a niekiedy kluczowy czynnik wpływający na charakter i zakres możliwych zdarzeń (Collier, Collier, 1991; Kamiński, 2010, passim).

Przy tym, w demokracjach przedstawicielskich takich jak polska, parlament stanowi jądro systemu politycznego - to tutaj partie i indywidualni posłowie łączą się w ugrupowania polityczne i obozy. Owe kolektywne byty ścierają się w debatach politycznych i podejmują decyzje dotyczące podtrzymania status quo lub zmiany istniejącego porządku. Tak było na przykład od początku polskiej transformacji ustrojowej (Chmaj, 1996). Skoro zatem w demokracji parlament jest jednym z głównych elementów systemu podejmowania decyzji, należy zwrócić uwagę na to, w jaki sposób wykorzystywano dostępny w poszczególnych kadencjach czas.

Prezentowane studium stanowi krok w stronę zrozumienia i wyjaśnienia działania polskiego parlamentu w procesie transformacji systemowej - jest on traktowany jako czynnik zmiany w demokratyzującym się systemie politycznym. Sejm traktowany jest tu jako podsystem, którego funkcją jest podejmowanie wiążących decyzji skierowanych na regulację działania systemu politycznego, społecznego i gospodarczego jako całości. Jednak nie będzie przedmiotem niniejszej prezentacji efektywność czy optymalizacja działania i prac ustrojodawczych, legislacyjnych, kontrolnych czy kreacyjnych Sejmu. Ich analiza może być przedmiotem badań w kolejnych etapach analizy działania systemu parlamentarnego. W niniejszym tekście chodzi jedynie o ukazanie niektórych faktów dotyczących wykorzystania czasu w Sejmie. Jest to zatem studium o rudymentarnym charakterze faktograficznym i rozpoznawczym.

W części pierwszej przedstawione zostaną przesłanki teoretyczne podjętego problemu badawczego. Czas został ukazany jako wymiar działania demokratycznego systemu politycznego. Zarysowano również niektóre obszary badań w naukach politycznych, w których wymiar czasu pojawia 
się jako tło, element albo też jako główna zmienna przy analizie aktywności organizacji i instytucji politycznych. Część druga poświęcona została celom, podejściu teoretycznemu i metodyce przeprowadzonych badań empirycznych - zostały tu opisane procedury, według których przygotowano i zanalizowano dane. $\mathrm{W}$ najobszerniejszym fragmencie przedstawiono wyniki badań empirycznych nad kilkoma zmiennymi: liczebnością dni obrad i posiedzeń (z uwzględnieniem rozkładów na poszczególne lata kalendarzowe kadencji), a także częstotliwością oraz długością dni obrad i posiedzeń. W części ostatniej zaprezentowano syntezę i interpretację wyników analiz.

\section{Czas w systemie demokratycznym jako problem badawczy}

Jednym z pojęć najczęściej wykorzystywanych do analizy zjawisk politycznych jest pojęcie systemu. Pojęcie to często uzupełnia się również przymiotnikiem wskazującym na szczególne cechy obiektu poddawanego analizie (np. ,system demokratyczny”, ,system autorytarny”, ,system totalitarny"). Najczęściej, badacze wykorzystujący pojęcie systemu zakładaja, że zarówno w ramach badanego obiektu, jak i pomiędzy nim a otoczeniem następuje komunikacja, a więc proces wymiany informacji $i$ energii (Easton, 1979).

Każde badanie procesu komunikacji wymaga przyjęcia niemego założenia o dynamice relacji między obiektami poddawanymi analizie. Założenie o dynamice generuje kolejne założenie - o „Zmianie stanów”, albo „zachodzeniu procesu”. Skoro zaś każda analiza zmiany obejmować musi przynajmniej dwa punkty w czasie, tym samym czas leży u podstaw każdego procesu komunikacyjnego oraz możliwości zaistnienia, trwania i ewolucji różnorakich systemów.

Czynnik czasu stanowi zatem również warunek sine qua non działania każdego systemu w sferze politycznej. Stąd wszystkie próby opisu i wyjaśniania działania systemów w sferze politycznej wymagają stwierdzenia, jak w ich ramach i na styku między systemami a ich otoczeniem w różnych momentach przetwarzane są oddziaływania. Na przykład, jeżeli podejmuje się wysiłek na rzecz zrozumienia demokratycznego parlamentu, tzn. stwierdzenia. „,co i jak działa w parlamencie”, albo też ,jak parlament sytuuje się w szerszym kontekście ustrojowym”, należy zawsze wziąc pod uwagę fakt, że dzieje się to w określonym czasie. Dopiero w konsekwencji uznania temporalności procesów politycznych 
w parlamencie - zarówno w ramach parlamentu, jak i na styku parlamentu i innych elementów systemu politycznego - może następować próba określania ich charakteru, np. wzmacniania lub osłabiania jego zdolności do efektywnego działania, albo też znaczenia w systemie politycznym. W ten sposób, czas staje się rodzajem zmiennej niezależnej, która dookreśla w badaniach zakres i charakter możliwych zdarzeń i działań politycznych.

Przy tym czas należy do zmiennych ciagłych. Jego pomiaru w badaniach społecznych dokonuje się zawsze $\mathrm{z}$ określoną dokładnością (np. dzień, miesiąc, rok). Mając też do dyspozycji dowolny okres, można go dzielić nieskończoną liczbę razy. W zasadzie zatem można przyjmować dowolną jednostkę dogodną dla analizy procesów politycznych. Co więcej, już sam wyróżniony okres jest fragmentem znacznie dłuższego kontinuum, którego początków możemy się domyślać, a którego końca nie znamy. W rezultacie, wybór momentu początkowego i końcowego analizy zawsze musi być podporządkowany dodatkowym kryteriom.

W politologii wymiar czasu zdecydowanie najczęściej traktuje się jako przedmiot rozważań w analizach zmian dotyczących strukturalnych i funkcjonalnych systemów politycznych i podmiotów w ich ramach, a zdecydowanie najrzadziej jako przedmiot godny odrębnych badań. Czas stanowi jedną z podstawowych zmiennych, jakie bierze się pod uwagę przy badaniach ewolucji systemów politycznych. Argumentuje się, że w określonym czasie rodzą się, dojrzewają, trwają, słabną i upadają systemy polityczne, a w ich ramach zmieniają się struktury, instytucje i organizacje polityczne (np. Blok, 2006, s. 76-85). Czas był naturalnym tłem dla rozważań dotyczących trwałości bądź zmiany ludzkich wzorów zachowań i instytucji politycznych, w tym formowania takich podstawowych kategorii jak państwo i naród, czy nowoczesność (Alonso, 1994, s. 387-390; Osborne, 1995).

W badaniach nad systemami demokratycznymi trudno jest wskazać pracę, w której nie brano by pod uwagę czynnika czasu, przynajmniej jako tła dla rozważań (Huntington, 1991, s. 12-13)1․ Współcześnie, coraz więcej uwagi przykłada się jednak do czynnika czasu jako jednego z głównych determinantów procesu politycznego, np. w badaniach wyborczych (tzw. electoral studies), czy w porównawczych badaniach systemów politycznych (comparative studies). W niektórych analizach zwraca się na

${ }^{1}$ Do takich prac można zaliczyć część literatury z zakresu filozofii polityki, choć $\mathrm{i}$ ich autorzy pisali często pod wpływem wymagań czasu. 
to, że czas może de facto przyspieszać, np. w wyniku wzrostu znaczenia technologii informacyjnych (Agre, 2002). W ten sposób, czas staje się nie tylko tłem dla podejmowanych działań w wymiarze fizycznym. Staje się też istotnym czynnikiem z punktu widzenia działania struktur politycznych, także o charakterze ponadnarodowym, takim jak Unia Europejska (Goetz, 2009, 2013).

Czas stanowi też istotny czynnik działalności politycznej w demokratycznych parlamentach. Nie tylko struktura podejmowania decyzji, ale i rozłożenie decyzji w czasie mogą wpływać na ich treść i jakość (Lupia, Strøm, 1995; Toshkov, Lowery, Carroll, Berkhout, 2013). Stąd stosunkowo liczne analizy dotyczyły problematyki strategicznego wykorzystania czasu (Rasmussen, Toshkov, 2011). Na przykład, Anderson i Woon zauważają, że na poziomie instytucji politycznych kontrola nad czasem podejmowania decyzji w parlamencie może prowadzić do uzyskiwania wpływu na treść decyzji podejmowanych w parlamencie (Anderson, Woon, 2014, s. 1-2). W podobnym tonie argumentują Gersen i Posner, według których regulowanie czasu podejmowania decyzji legislacyjnych może być bardziej efektywne niż regulowanie treści samej legislacji (Gersen, Posner, 2007, s. 544-545). Część badaczy zwraca z kolei uwagę na to, że skracanie kadencji, zwłaszcza w systemach większościowych, przyczynia się do optymalizowania szans na reelekcję. Na przykład, Cargill i Hutchison oraz Kayser argumentowali, że pod wpływem sprzyjającej koniunktury politycznej zwiększać się mają szanse obozu rządzącego na zwiększenie liczby przysługujących mu miejsc w parlamencie (Cargill, Hutchinson, 1991, s. 733; Kayser, 2005).

We współczesnych badaniach nad polskim parlamentaryzmem można wyróżnić analizy wykorzystujące zmienną czasu w różny sposób. Czas traktowany bywa zarówno jako tło dla szerszych procesów politycznych, na przykład transformacji systemowej (Nalewajko, Wesołowski, 2007), jak i istotny aspekt strategicznego działania klubów i kół parlamentarnych oraz indywidualnych posłów (Kasianiuk, 2016). Czas niekiedy jest uznawany za element procesu legislacyjnego zachodzącego w Sejmie, lub szerzej - parlamencie (Dudzińska, 2015; Sokołowski, Poznański, 2008; Zubek, Klüver, Matczak, Zalasiński, 2012). W żadnej z wymienionych prób nie próbowano jednak scharakteryzować czasu jako zmiennej, która nie byłaby powiązana $\mathrm{z}$ analizą innych zmiennych, np. działalności legislacyjnej, kontrolnej czy kreacyjnej. Dlatego wydaje się, że próba taka może stanowić istotne uzupełnienie istniejących analiz i punkt wyjścia dla analiz kolejnych. 


\section{Cel, podejście teoretyczne i metodyka badania}

\section{Cel}

Celem prezentowanego tu badania empirycznego było stwierdzenie podstawowych faktów dotyczących wykorzystania czasu w polskim parlamencie, w szczególności liczebności i długości posiedzeń, od początku transformacji systemowej do końca ostatniej pełnej kadencji, tj. w okresie 1989-2015. W badaniu nastapiła próba określenia charakterystyki poszczególnych kadencji oraz stwierdzenia, czy zasadne jest wyróżnienie podokresów.

Przyjęto, że działalność Sejmu jest rozdzielana przez instytucjonalne reguły wyborów powszechnych na czteroletnie kadencje. Czas trwania poszczególnych kadencji został ukazany w tabeli poniżej. Do kadencji pełnych należały: II, III, IV, VI oraz VII. Natomiast kadencjami skróconymi były kadencje $\mathrm{X}$, I oraz $\mathrm{V}$.

Tabela 1

Czas trwania poszczególnych kadencji w latach 1989-2015

\begin{tabular}{||l|c|c|c||}
\hline Wyszczególnienie & Dzień rozpoczęcia & Dzień zakończenia & $\begin{array}{c}\text { Liczba dni } \\
\text { kadencji }\end{array}$ \\
\hline Sejm X kadencji & 04.07 .1989 & 25.10 .1991 & 843 \\
\hline Sejm I kadencji* & 25.11 .1991 & 30.05 .1993 & 552 \\
\hline Sejm II kadencji & 14.10 .1993 & 20.10 .1997 & 1467 \\
\hline Sejm III kadencji & 20.10 .1997 & 18.10 .2001 & 1459 \\
\hline Sejm IV kadencji & 19.10 .2001 & 18.10 .2005 & 1460 \\
\hline Sejm V kadencji & 19.10 .2005 & 04.11 .2007 & 746 \\
\hline Sejm VI kadencji & 05.11 .2007 & 07.11 .2011 & 1463 \\
\hline Sejm VII kadencji & 08.11 .2011 & 11.11 .2015 & 1464 \\
\hline
\end{tabular}

* Dni rozpoczęcia i zakończenia kadencji podawane są różnie, zwłaszcza, jeżeli porównać je między źródłami Sejmu i Senatu.

Z naturalnych względów liczba dni kadencji w pełnych czteroletnich kadencjach była bardzo zbliżona i wynosiła od 1459 do 1467 dni. Natomiast liczba dni kadencji skróconych była różna i wynosiła od 552 dni (w kadencji I), przez 746 dni (w kadencji V) do 843 dni (w kadencji X)².

2 Sejm X kadencji rozpoczął obrady latem 1989, w odróżnieniu od wszystkich pozostałych Sejmów, które rozpoczynały się jesienią roku kalendarzowego. W przypadku kadencji IV nastąpił wzrost liczby dni obrad Sejmu. Można domniemywać, że 
Podział na hipotetyczne podokresy był podporządkowany innym kryteriom. Ostatecznie, osiem kadencji obejmujących czas trwania Sejmu od 1989 roku został podzielony na trzy podokresy, i to zasadność takiego podziału została poddana ocenie w badaniu. Przyjęty podział na podokresy został ustalony na podstawie wstępnej obserwacji kilku cech całego badanego okresu i poszczególnych kadencji. Po pierwsze, omawiany okres obejmował zarówno kadencje pełne, jak i skrócone. Po drugie, dwie spośród trzech kadencji skróconych pojawiły się w początkowym okresie transformacji. Po trzecie, po kadencjach skróconych nastapiła seria kadencji pełnych. Po czwarte, po serii kadencji pełnych nastapiła jedna kadencja skrócona, po której nastąpiły dwie kadencje pełne. Ponadto, w analizowanym czasie można zauważyć zróżnicowaną sytuację polityczną. Pierwsze dwie kadencje charakteryzowała znaczna ambiwalentność polityczna, mierzona częstością zmiany składów rządów. Kolejne kadencje pełne to czas rządów bardziej stabilnych. Szczególny okres polityczny rozpoczął się natomiast wraz z V kadencją - w jej trakcie nastąpiła silna, trwająca przez cały badany okres, polaryzacja między dwiema partiami o pochodzeniu postsolidarnościowymi.

W konsekwencji, na użytek badania przyjęto następujący podział na podokresy: A, B oraz C:

A. kadencje X i I - kadencje skrócone z początku transformacji systemowej $^{3}$;

B. kadencje II-VI - kadencje pełne;

C. kadencje V-VII - jedna kadencja skrócona (V) i dwie kadencje pełne.

Podejście teoretyczne: parlament jako system

Za „system polityczny” rozumiano w badaniu zbiór współzależnych jednostek politycznych (podsystemów), w którym podejmowane są decyzje dotyczące kształtu wewnętrznych współzależności i relacji systemu z otoczeniem. W badaniu przyjęto założenie, że parlament jest systemem, na który składają się Sejm i Senat. „System parlamentarny” ma w okre-

było to związane z koniecznością dostosowania polskiego prawodawstwa do wymagań Unii Europejskiej.

3 Sejm X i częściowo Sejm I kadencji obradowały w ramach regulaminu przewidującym dwie sesje organizujące jego działania - jesienną i wiosenną. W regulaminie z 30 lipca 1992 roku sesje już nie występują (Uchwała Sejmu Rzeczypospolitej Polskiej z dnia 30 lipca 1992 r. Regulamin Sejmu Rzeczypospolitej Polskiej, 1992). 
ślonym czasie zdolność do przetwarzania różnego typu impulsów. Impulsy te pochodzić mogą zarówno ze środowiska zewnętrznego (otoczenia), jak i ze środowiska wewnętrznego. W ten sposób system parlamentarny stanowi system adaptacyjny i względnie odosobniony, którego aktywność ani nie wynika tylko z impulsów z otoczenia, ani też z procesów wewnętrznych. W systemie parlamentarnym Sejm stanowi główny czynnik dynamizujący działanie całego układu.

Założono również, że parlament ma zdolność przetwarzania impulsów w określonym tempie, co może być związane ze zdolnością działania pojedynczych parlamentarzystów oraz charakterem działania innych podmiotów (np. Kancelarii Sejmu i klubów), jak również innych konstytucyjnych organów władzy publicznej. Ponadto przyjęto, że jeżeli sytuacja $\mathrm{w}$ otoczeniu jest stabilna, to im więcej czasu przeznaczonego jest na pracę Sejmu, tym większe możliwości realizowania jego funkcji systemowej. Teoretycznie więc możliwe są okresy „przeciążenia” i „rozprężenia" systemu. Przeciążenie systemu występować powinno w sytuacjach, kiedy liczba i typ spraw jest zbyt duża względem możliwości organizacyjnych, obejmujących także czas przeznaczony na posiedzenia ${ }^{4}$. Jednocześnie, przyjęto, że parlament może zmieniać charakterystykę działania w poszczególnych kadencjach.

Przy tym, panujące w Polsce prawo i regulacje ograniczały zdolność Sejmu do strategicznego skracania kadencji - w całym badanym okresie panowało prawo wyborcze realizujące założenia systemu proporcjonalnego, co przekładało się na faktyczne zawieranie koalicji rządowych ${ }^{5}$.

\section{Operacjonalizacja}

Przyjęto, że system parlamentarny działa zawsze $\mathrm{w}$ określonym czasie oraz, że można wyróżnić wymiary owego czasu. Na użytek badania wyróżniono dwa, wzajemnie powiązane wymiary czasu - fizyczny i organizacyjny. Czas został zdefiniowany operacyjnie, poprzez odniesienie do zmiennych opartych na oficjalnych danych (głównie sprawozdań stenograficznych z posiedzeń plenarnych udostępnianych przez Kancelarię Sejmu).

${ }^{4}$ Stanowi to istotną wskazówkę, jeżeli chce się oceniać działalność parlamentarną w dłuższym okresie. Aspekt ten nie był jednak przedmiotem prezentowanych analiz empirycznych.

${ }^{5}$ W badanym okresie skrócenie kadencji Sejmu nastąpiło w V kadencji. Spowodowało to utratę władzy przez Prawo i Sprawiedliwość. 
W efekcie, przez czas w sensie fizycznym rozumie się tu liczbę dni kadencji Sejmu. Jest to zmienna obejmująca całość dostępnego fizycznie czasu, wyznaczonego datami początku i końca kadencji (patrz tabela 1). Przez czas w sensie organizacyjnym rozumie się tu zestaw dwóch zmiennych: liczby dni obrad Sejmu i liczby posiedzeń Sejmu.

Należy zauważyć, że tak zdefiniowany czas organizacyjny ma charakter bazowy, to znaczy nie obejmuje innych możliwych zmiennych czasu organizacyjnego. Inne zmienne w ramach czasu organizacyjnego mogą obejmować: liczbę posiedzeń komisji i podkomisji sejmowych, zespołów parlamentarnych, klubów i kół, a także liczbę posiedzeń grup bilateralnych. Poza zakresem tej definicji pozostaje także m.in. czas spędzany przez parlamentarzystów indywidualnie: w swoich biurach poselskich, na spotkaniach $\mathrm{z}$ wyborcami oraz na posiedzeniach klubów ${ }^{6}$.

Przyjęto następujące wskaźniki zakresu wykorzystania czasu organizacyjnego w systemie parlamentarnym:

- „częstotliwość dni obrad” - średnia liczba dni kadencji przypadających na dzień obrad;

- „częstotliwość posiedzeń” - średnia liczba dni kadencji przypadających na posiedzenie;

- „długość posiedzeń” - średnia liczba dni obrad przypadających na posiedzenie.

Procedura symulacji danych i analizy

Dla zbadania charakterystyki wykorzystania czasu dostępne oficjalnie dane nie są wystarczające. Dlatego zdecydowano się na symulowanie wartości niektórych zmiennych. Symulacja skierowana była na uzyskanie wiedzy o tym, jakiego poziomu wartości zmiennych można by się spodziewać w kadencjach poddawanych uzupełnieniu (skróconych), jeżeli zachowana byłaby dynamika działań Sejmu w rozpatrywanej kadencji. Cel ten znajduje dodatkowe uzasadnienie, jeżeli zbada się liczbę dni obrad i liczbę posiedzeń w kalendarzowych latach kadencji. Badanie takie również zostało przeprowadzone, a jego wyniki znaleźć można dalej.

${ }^{6}$ Analiza dotyczyła lat 1989-2015. Niemal wszystkie statystyki powstały na podstawie danych zgromadzonych na stronie internetowej Sejmu Rzeczypospolitej Polskiej. 
$\mathrm{Na}$ podstawie analizy poszczególnych kadencji skróconych oraz średnich dla całego okresu dokonano symulacji liczby dni obrad i liczby posiedzeń. W celu oszacowania liczby dni obrad i liczby posiedzeń w symulacji dokonano następujących działań. Najpierw (1), określono udział liczby faktycznych dni kadencji w średniej liczbie dni w kadencji (na podstawie uśrednienia liczby dni we wszystkich kadencjach pełnych). Podzielono tu faktyczną liczbę dni przez średnią liczbę dni $(1462,6)$. Następnie (2), powstałą wartość odjęto od wartości „1”, by określić hipotetyczny czas pozostały do wykorzystania w rozpatrywanej kadencji. W kolejnym kroku (3), pomnożono powstałą dla kadencji pełnych wartość dla zmiennej „liczba dni obrad” (względnie „liczba posiedzeń”) oraz dodano do niej faktyczną wartość liczby dni obrad (liczby posiedzeń) dla rozpatrywanej kadencji. Na przykład, dla kadencji X działanie przebiegało następująco:

- dla zmiennej ,liczba dni obrad”:

$$
\begin{aligned}
& \text { (1) } 843: 1462,6=0576 ; \text { (2) } 1-0,576= \\
& =0,424 ; \text { (3) } 0,424 \times 305,4+179=308
\end{aligned}
$$

- dla zmiennej „liczba posiedzeń”:

$$
\begin{aligned}
& \text { (1) } 843: 1462,6=0576 ; \text { (2) } 1-0,576= \\
& =0,424 ; \text { (3) } 0,424 \times 109+79=125
\end{aligned}
$$

Wyniki symulacji przeprowadzonych początkowo dla kadencji skróconych, zostały rozszerzone na kadencje pełne. Okazało się, że symulacje dla kadencji pełnych prowadzą do uzyskania wyników bardzo bliskich wartościom faktycznym (Patrz tabela 2).

Analiza zmiennych „liczba dni obrad” oraz „liczba posiedzeń” została przeprowadzona $\mathrm{z}$ wykorzystaniem danych symulowanych i częściowo danych faktycznych. Analiza zmiennych „częstotliwość dni obrad”, „częstotliwość posiedzeń” oraz „długość posiedzeń” oparta była wyłącznie na danych faktycznych. W badaniu zastosowano standardowe metody analizy statystycznej (w tym analizę średnich oraz odchylenia standardowego).

\section{Wyniki badań}

Analiza statystyczna danych dotyczących kadencji X-VII prowadzi do wniosku, że poszczególne kadencje oraz wyróżnione podokresy różnią się niekiedy bardzo znacząco. 


\section{Liczba i rozkład dni obrad i posiedzeń}

Wiedza na temat liczby dni obrad i liczby posiedzeń Sejmu w kadencji pozwala na ocenę zakresu wykorzystania dostępnego w kadencji czasu.

Można byłoby się spodziewać, że w przypadku kadencji pełnych, zarówno liczba dni obrad, jak i liczba posiedzeń Sejmu były zbliżone. W rzeczywistości jednak badane okresy różniły się zarówno średnią liczbą dni obrad, jak i liczbą posiedzeń oraz ich średnimi.

Tabela 2

Faktyczna i symulowana liczba dni i posiedzeń Sejmu w kadencjach X-VII (w nawiasach - przybliżone dane symulowane) ${ }^{7}$

\begin{tabular}{|c|c|c|c|c|c|c|c|c|c|}
\hline Okres & \multicolumn{2}{|c|}{$\overline{\mathbf{A}}$} & \multicolumn{3}{|c|}{$\overline{\mathbf{B}}$} & \multicolumn{3}{|c|}{$\overline{\mathrm{C}}$} & \multirow{2}{*}{\begin{tabular}{|c|} 
Śred- \\
nia dla \\
kadencji \\
pełnych
\end{tabular}} \\
\hline Wyszczególnienie & $\mathbf{X}-s$ & $\mathbf{I}-s$ & $\mathbf{I I}-p$ & $\begin{array}{l}\text { III } \\
-p\end{array}$ & $\begin{array}{l}\mathbf{I V} \\
-p\end{array}$ & $\mathbf{V}-s$ & $\begin{array}{r}\mathbf{V I} \\
-p\end{array}$ & $\begin{array}{l}\text { VII } \\
-p\end{array}$ & \\
\hline Liczba dni kadencji & 843 & 552 & 1467 & 1459 & 1460 & 746 & 1463 & 1464 & 1463 \\
\hline Liczba dni obrad* & $\begin{array}{c}174 \\
(308)\end{array}$ & $\begin{array}{r}* * 142 \\
(332)\end{array}$ & $\begin{array}{r}297 \\
(296)\end{array}$ & $\begin{array}{r}315 \\
(316)\end{array}$ & $\begin{array}{r}334 \\
(335)\end{array}$ & $\begin{array}{r}146 \\
(296)\end{array}$ & $\begin{array}{r}294 \\
(294)\end{array}$ & $\begin{array}{r}287 \\
(287)\end{array}$ & 305 \\
\hline Liczba posiedzeń & $\begin{array}{c}79 \\
(125)\end{array}$ & $\begin{array}{r}45 \\
(113)\end{array}$ & $\begin{array}{r}115 \\
(115)\end{array}$ & $\begin{array}{r}119 \\
(119)\end{array}$ & $\begin{array}{r}109 \\
(109)\end{array}$ & $\begin{array}{r}48 \\
(101)\end{array}$ & $\begin{array}{r}100 \\
(100)\end{array}$ & $\begin{array}{r}102 \\
(102)\end{array}$ & 109 \\
\hline $\begin{array}{l}\text { Średnia liczba dni obrad } \\
\text { w okresie }\end{array}$ & & $\begin{array}{l}58 \\
20)\end{array}$ & & $\begin{array}{l}315 \\
(315)\end{array}$ & & & $\begin{array}{c}242 \\
(292)\end{array}$ & & \\
\hline $\begin{array}{l}\text { Średnia liczba posiedzeń } \\
\text { w okresie }\end{array}$ & & $\begin{array}{l}62 \\
19)\end{array}$ & & $\begin{array}{c}114 \\
(114)\end{array}$ & & & $\begin{array}{c}83 \\
(101)\end{array}$ & & \\
\hline
\end{tabular}

\section{Legenda:}

$p$ - kadencja pełna;

$s$ - kadencja skrócona.

* Liczba dni obrad została zrekonstruowana na podstawie sprawozdań posiedzeń Sejmu.

** Ze względu na brak dostępu do niektórych stenogramów z posiedzeń, dla obliczenia liczby dni obrad wykorzystano średnią dla każdej kadencji.

Źródło: Obliczenia własne na podstawie danych www.senat.gov.pl, www.archiwaprzelomu.pl, www.sejm.gov.pl.

Analiza danych faktycznych pokazuje, że najwięcej dni obrad miało miejsce w kadencji IV (334), a najmniej w kadencji VII - 287. Należy zauważyć, że do kadencji IV liczba dni obrad wahała się (między 297 a 334), następnie zaś spadała, by osiagnąć wartość 287 w kadencji VII. Podobne wyniki można zaobserwować, badając dane symulowane.

${ }^{7}$ W kadencji II dni obrad Sejmu było 297. Dane obliczone na podstawie Sprawozdań stenograficznych z posiedzeń Sejmu (oprócz kadencji I). 
Najwyższe wartości dla danych symulowanych odnotowano dla okresu A (kadencje X i I), zaś najmniejsze dla okresu C (kadencje V-VII). Średnia liczba dni obrad w symulacji dla okresu A wynosiła 320, B - 315, zaś C - 292. Przy tym różnice średnich między okresem A i B były nieznaczne (około $2 \%$ dla liczby dni obrad i około $5 \%$ dla posiedzeń), zaś między B i C były bardziej widoczne (dla dni obrad - 8\% i dla posiedzeń $-27 \%)^{8}$. Z kolei symulacja liczby posiedzeń wskazuje na wahania: między 125 w kadencji X i 100 w kadencji VI. Przy tym liczba posiedzeń wahała się między kadencjami X i IV. Dopiero potem ustabilizowała się.

W całym analizowanym czasie liczba dni obrad i liczba posiedzeń zmniejszyła się. Tendencje te są takie same zarówno dla danych faktycznych, jak i symulowanych. Zjawisko to będzie przedmiotem analiz w kolejnych częściach.

\section{Wykres 1. Symulowana liczba dni obrad i liczba posiedzeń w kadencjach X-VII}

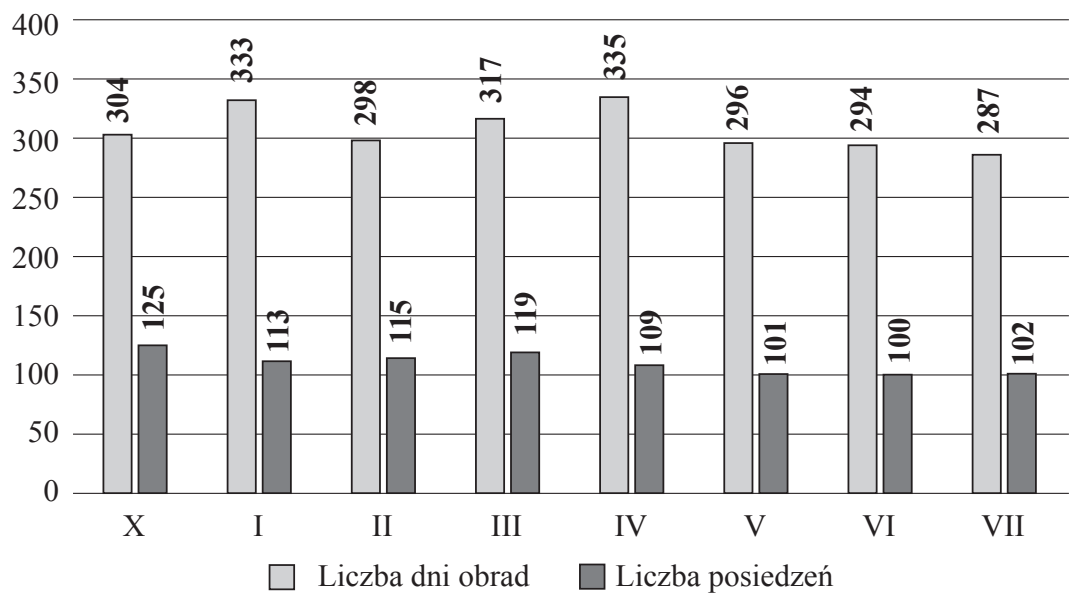

Dane dotyczące liczby dni obrad i posiedzeń w trakcie kolejnych lat kalendarzowych kadencji stanowią uzupełnienie powyższych wyników badań. Ukazują bowiem dynamikę wykorzystania czasu w każdej z analizowanych kadencji ${ }^{9}$. Z uwagi na to, że analiza danych symulowanych

${ }^{8} \mathrm{~W}$ obu przypadkach wartością podstawową (100\%) była wartość z okresu poprzedzającego.

9 Obliczenie następowało poprzez zsumowanie dni obrad Sejmu w roku kalendarzowym. 
mogłaby być tu obciążona zbyt dużym błędem, uwaga skupiła się na danych faktycznych i to dotyczących przede wszystkim lat pełnych (tj. lat w których nie odbywały się wybory parlamentarne).

Warto odnotować, że w pierwszym roku kalendarzowym kadencji średnia liczba dni obrad w okresie A wynosiła ponad 19, w B - 18, zaś w C - tylko około 12. Wydaje się, że efekt ten mógł być jedynie częściowo wywołany przez fakt, że kadencja $\mathrm{X}$ rozpoczynała się w połowie roku, nie zaś, jak pozostałe kadencje - jesienią. Wprawdzie w kadencji X odbyło się więcej posiedzeń niż średnia w okresie, jednak w kadencji I posiedzeń było zaledwie kilka ${ }^{10}$. To powoduje, że średnia dla okresu A jest zbliżona do średniej dla okresu B.

$\mathrm{W}$ drugim pełnym roku kalendarzowym kadencji we wszystkich podokresach liczba dni obrad była bardzo zbliżona - od 76 do 78 dni. Trzeci rok kadencji możliwy jest do oceny jedynie dla okresu B - odbyło się w nim średnio 81 dni obrad. Podobnie w roku czwartym - dni obrad było średnio 85 dni. Na tym tle wyróżnia się kadencja IV, w której w kolejnych latach było najpierw 76, potem 90, a następnie 99 dni obrad. Skok w liczbie dni obrad był tu więc bardzo znaczący. Wydaje się, że mogło to być związane z koniecznością przystosowania polskiego prawodawstwa do regulacji

\section{Wykres 2. Liczba dni obrad Sejmu w poszczególnych latach kalendarzowych kadencji}

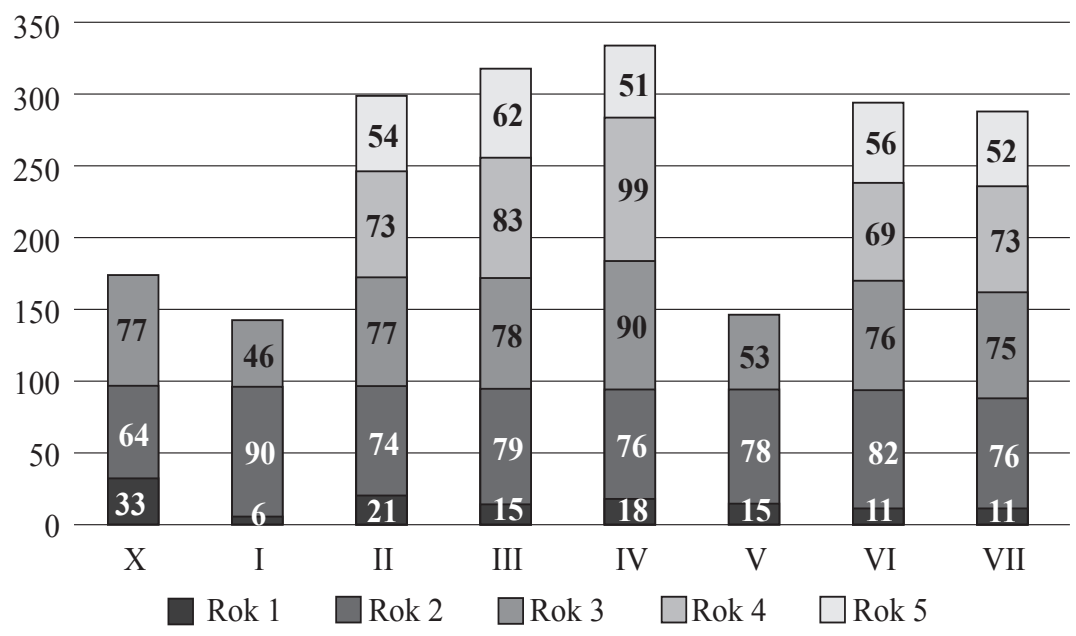

\footnotetext{
10 Średnia dla wszystkich pierwszych lat kalendarzowych wynosiła 16,25.
} 
Unii Europejskiej ${ }^{11}$. Zdecydowanie mniej dni obrad w trzecim i czwartym roku kadencji było w kadencjach VI i VII, tj. pełnych kadencjach okresu C - było to odpowiednio od 69 do 76 dni. Przy tym w okresie C, odwrotnie niż w okresie B, wraz z upływem czasu, liczba dni obrad spadała.

W całym badanym okresie liczba posiedzeń Sejmu odbytych w roku kalendarzowym była stabilna, wynosząc średnio w pełnych latach kadencji około 28 i wahając się między 24 a 33. Dość zróżnicowany był pierwszy rok trwania kadencji - wyłączając znacznie odbiegającą od średniej kadencję X odbyło się w niej od 4 do 9 posiedzeń. Natomiast identyczne pod względem liczby posiedzeń w ostatnim roku kalendarzowym były kadencje II, VI i VII (19). Nieco mniej posiedzeń było w kadencji IV (15) i nieco więcej w kadencji III (23 posiedzenia).

\section{Wykres 3. Liczba posiedzeń w poszczególnych latach kalendarzowych kadencji X-VII}

140

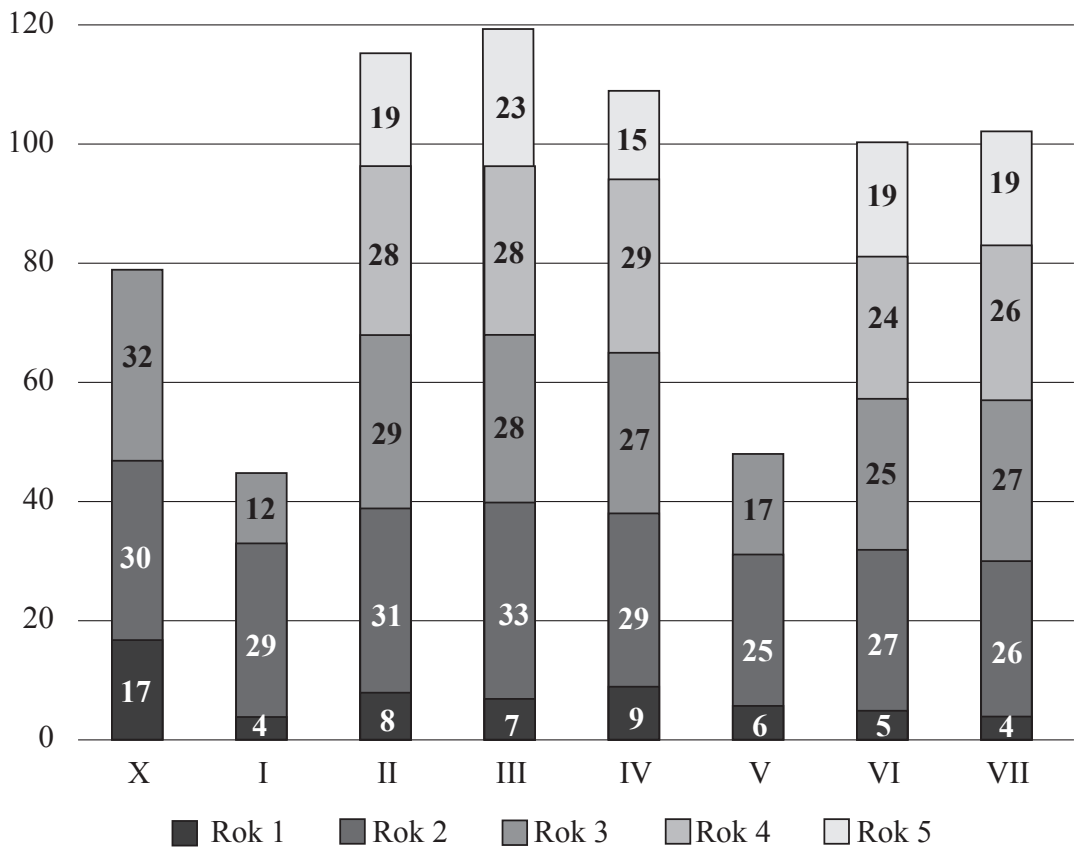

11 Jest to jednak obserwacja niepotwierdzona badaniami porównawczymi. 
Częstotliwość dni obrad i posiedzeń

Badanie częstotliwości dni obrad pozwala na określenie udziału czasu przeznaczonego na pracę w parlamencie w czasie całej kadencji. Z kolei analiza częstotliwości posiedzeń pozwala na określenie, jak Sejm operował czasem, dokonując przerw między posiedzeniami.

Analiza częstotliwości dni obrad i posiedzeń na podstawie danych faktycznych wskazuje na ich odmienne dynamiki. W oczy rzuca się przede wszystkim faktyczny wzrost średniej liczby dni kadencji przypadających na jedno posiedzenie. W kadencji X było to 10,67, natomiast w kadencji VII - już 14,35. Przy tym najwyższa średnia dotyczyła kadencji V (15,54).

$\mathrm{Z}$ analizy wynika także, że średnia liczba dni kadencji przypadających na dzień obrad wahała się w badanym okresie dość znacznie - było to między 3,89 a 5,01 (patrz wykres 4). Z tym, że średnia w wyróżnionych trzech okresach rosła - dla okresu A wynosiła ona 4,37, dla B - 4,63, zaś C - 5,06. Podobny wzrost dotyczył średniej liczby dni kadencji przeznaczanych na jedno posiedzenie - było to: 11,47 (okres A), 12,80 (okres B) i 14,84 (okres C). Znów zatem różnica między okresem $\mathrm{B}$ oraz $\mathrm{C}$ okazała się największa.

Ponadto, wahania obu zmiennych były większe w okresach A i B, niż w okresie $\mathrm{C}$ - od kadencji V częstotliwość dni obrad była stabilna (na poziomie ok. 5,05), zaś częstotliwość posiedzeń spadała. Co więcej, przed $\mathrm{V}$ kadencją średnie przerwy między posiedzeniami były większe - o 2-3 dni, a po niej mniejsze - o około 1 dnia.

\section{Wykres 4. Częstotliwość dni obrad posiedzeń w kadencjach X-VII}

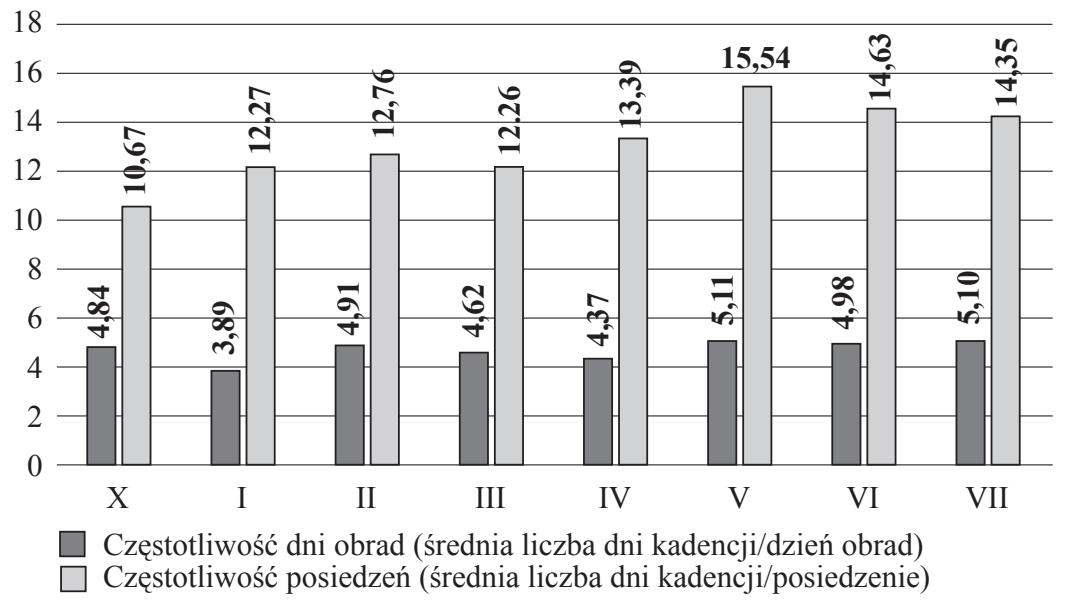




\section{Długość posiedzeń}

Dzięki wiedzy o średniej liczbie dni obrad przypadających na jedno posiedzenie można stwierdzić, ile czasu poświęcano w Sejmie na jedną sesję.

Okazało się, że średnia liczba dni obrad przypadających na jedno posiedzenie wahała się znacząco w kadencjach X-I, rosła w kadencjach II-IV i spadała w kadencjach V-VII (patrz wykres 5). Z tym, że średnia liczba dni trwania jednego posiedzenia w całym badanym okresie wynosiła 2,81. Średnia liczba dni obrad była największa w kadencji I $(3,16)$, zaś najmniejsza w kadencji X $(2,20)$. Warto też odnotować, że pomiędzy kadencjami w okresie A dostrzegalna jest największa różnica $\mathrm{w}$ długości posiedzeń $(0,9)$. Podobne, choć już nie tak znaczące różnice odnotowano w okresie B między kadencjami III i IV $(0,42)$.

Kadencje I, IV i V miały średnio najdłuższe posiedzenia. W kadencji I odnotowano największe wahania w liczbie dni obrad przypadających na posiedzenie (odchylenie standardowe to 1,11). Niższe wartości miały kadencje III, IV i V (odchylenie standardowe odpowiednio 0,98, 1,03, $0,99)$. Najmniejsze wahania liczby dni obrad na posiedzenie odnotowano w kadencji VI (odchylenie standardowe 0,74).

\section{Wykres 5. Średnia liczba dni obrad przypadających na posiedzenie}

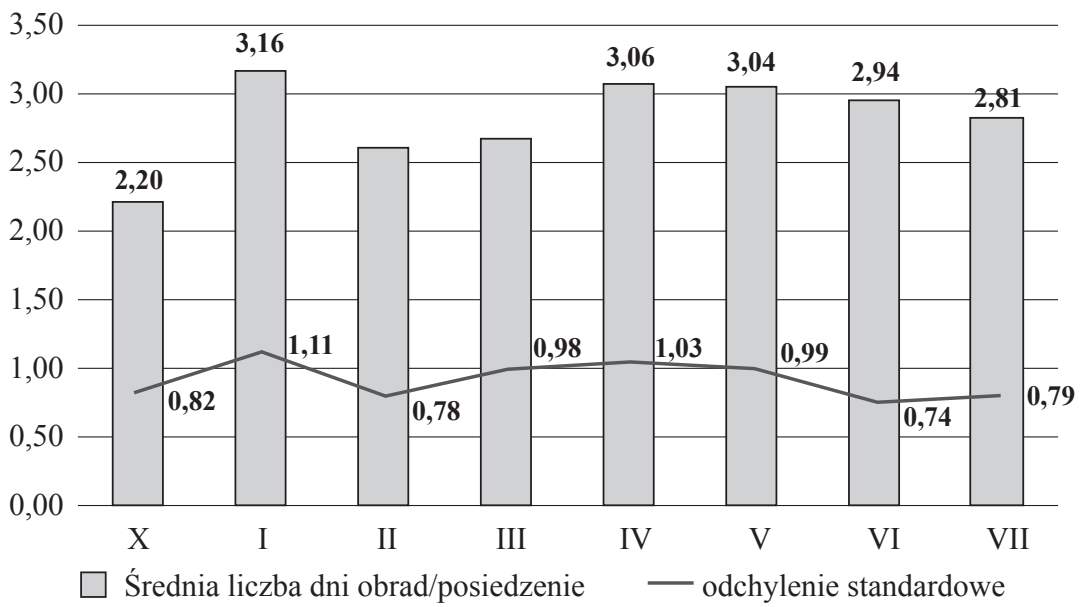

Warto w tym kontekście zwrócić uwagę na średnią liczbę dni obrad przypadających na jedno posiedzenie Sejmu w poszczególnych latach 
kalendarzowych kadencji (patrz tabela 3). W niemal wszystkich kadencjach widoczny jest trend - średnia liczba dni obrad przypadających na posiedzenie rosła do trzeciego roku kadencji (osiaggając maksymalną wartość 2,95 ), a następnie stabilizowała się na nieco niższym poziomie $(2,92-2,93)$.

Średnia liczba dni przypadających na posiedzenie była dość zróżnicowana: najmniej dni pracowano w kadencji X $(2,16)$, a najwięcej w kadencji IV $(2,95)$. Oprócz kadencji X stosunkowo niską średnią wyróżniały się kadencje II oraz III, w których średnia liczba dni wynosiła odpowiednio 2,63 oraz 2,60. Z drugiej strony, wysoką średnią odnotowano w kadencji V $(2,91)$. Wyniki dla kadencji VI i VII są na poziomie średniej ogólnej (tj. około 2,81). Zdecydowanie najdłużej trwały posiedzenia w kadencji IV, zwłaszcza od trzeciego roku jej trwania (wartości 3,33-3,41). Przy tym, średnia liczba dni posiedzenia była najniższa w pierwszym roku kadencji I (wynosiła zaledwie 1,5), zaś w ostatnim, niepełnym, trzecim roku była bardzo wysoka - 3,83. Zdecydowanie największe odchylenie standardowe odnotowano dla kadencji I - 0,53, zaś najmniejsze - kadencja VII $(0,08)$.

W niemal wszystkich kadencjach (tj. oprócz kadencji II), najmniejsza liczba dni obrad była w pierwszym roku kadencji i liczba ta raczej rosła do końca kadencji.

Tabela 3

Średnia liczba dni obrad przypadających na posiedzenie Sejmu w poszczególnych latach kadencji

\begin{tabular}{|c|c|c|c|c|c|c|c|c|c|}
\hline Okres & \multicolumn{2}{|c|}{$\overline{\bar{A}}$} & \multicolumn{3}{|c|}{$\overline{\text { B }}$} & \multicolumn{3}{|c|}{$\overline{\mathrm{C}}$} & \multirow[b]{2}{*}{$\begin{array}{l}\text { Średnia } \\
\text { dla roku } \\
\text { kadencji }\end{array}$} \\
\hline $\begin{array}{l}\text { Rok } \\
\text { kalendarzowy }\end{array}$ & $\mathbf{X}$ & I & II & III & IV & V & VI & VII & \\
\hline Rok 1 & 1,94 & 1,50 & 2,63 & 2,14 & 2,00 & 2,50 & 2,20 & 2,75 & 2,21 \\
\hline Rok 2 & 2,13 & 3,10 & 2,39 & 2,39 & 2,62 & 3,12 & 3,04 & 2,92 & 2,71 \\
\hline Rok 3 & 2,41 & 3,83 & 2,66 & 2,79 & 3,33 & 3,12 & 3,04 & 2,78 & 2,99 \\
\hline Rok 4 & & & 2,61 & 2,96 & 3,41 & & 2,88 & 2,81 & 2,93 \\
\hline Rok 5 & & & 2,84 & 2,70 & 3,40 & & 2,95 & 2,74 & 2,92 \\
\hline Średnia dla kadencji & 2,16 & 2,81 & 2,63 & 2,60 & 2,95 & 2,91 & 2,82 & 2,80 & \\
\hline Średnia dla okresu & & & & 2,72 & & & 2,84 & & \\
\hline
\end{tabular}

Ponadto, długość posiedzeń w poszczególnych latach kalendarzowych kadencji różniła się między badanymi okresami. Średnia w okresie A była najniższa $(2,48)$, zaś w okresie C najwyższa $(2,84)$. Można zatem 
stwierdzić, że w całym badanym okresie posiedzenia Sejmu były coraz dłuższe.

\section{Podsumowanie}

Celem prezentowanych badań było rozpoznanie podstawowych faktów dotyczących sposobu wykorzystywania czasu w polskim Sejmie w latach 1989-2015. Zwrócono uwagę na aspekt fizyczny i organizacyjny czasu, co zdefiniowano operacyjnie za pomocą kilku zmiennych: podstawowych (dni obrad Sejmu, posiedzenia Sejmu) oraz wtórnych (częstotliwość dni obrad, częstotliwość posiedzeń oraz długość posiedzeń).

Przyjęto, że analiza przebiegać będzie na trzech poziomach: całości badanego czasu (lata 1989-2015), poszczególnych kadencji (kadencje $\mathrm{X}$-VII) oraz trzech krótszych podokresów (A - kadencje X-I, B - kadencje II-IV oraz C - kadencje V-VII), wyróżnionych z pomocą kryteriów instytucjonalnych i odnoszących się do dynamiki procesów politycznych. Teoretyczny podział na podokresy stanowił dodatkowe zagadnienie badawcze - podjęto próbę zweryfikowania, czy podział ów znajduje potwierdzenie w danych empirycznych.

Wyniki zrealizowanych badań wydają się dość interesujące. W całym analizowanym czasie spadała liczba dni obrad. Zmniejszyła się też liczba posiedzeń. Tak więc, w tych wymiarach, czasu na pracę w Sejmie było coraz mniej. Można jednak również stwierdzić, że w całym badanym okresie posiedzenia Sejmu były coraz dłuższe. W oczy rzuca się też systematyczny wzrost średniej liczby dni kadencji przypadających na jedno posiedzenie. Oznacza to, że najmniejsze przerwy między posiedzeniami były na początku, a największe - na końcu analizowanego okresu. Odmienną charakterystyką odznaczały się wyniki dotyczące długości posiedzeń. Okazuje się, że średnia liczba dni obrad przypadających na posiedzenie wahała się znacząco w kadencjach X-I, rosła w kadencjach II-IV i spadała w kadencjach V-VII.

W świetle wyników badań podział na wspomniane okresy okazał się mniej różnicujący niż pierwotnie zakładano. Wyniki analiz wskazują raczej na to, że bardziej zasadne jest rozróżnienie na okres obejmujący kadencje X-IV (a więc połączone okresy A i B) oraz V-VII (dotychczasowy okres C).

Pierwszym z argumentów przemawiających za taką interpretacją wyników jest obserwacja, że badane okresy różniły się zarówno średnią 
liczbą dni obrad, jak i średnią liczbą posiedzeń. Zwłaszcza analiza danych symulowanych wskazuje, że zarówno liczba dni obrad, jak i liczba posiedzeń znacząco wahały się między kadencjami X i IV (a więc w okresach A i B), a później systematycznie spadały. Należy również odnotować znaczące różnice między średnimi w liczbie dni obrad i posiedzeń, co przede wszystkim dotyczy granicy między okresami B oraz C (średnia dla okresu A była na zbliżonym poziomie do średniej dla okresu B).

Drugim argumentem na rzecz tezy o istnieniu dwóch a nie trzech okresów wykorzystania czasu w polskim Sejmie jest charakterystyka faktycznej liczby dni obrad w poszczególnych latach kalendarzowych kadencji analizowanych dla kadencji pełnych. Wyniki analiz dotyczące kadencji II-IV (a więc okresu B) mają inną charakterystykę niż dane dotyczące kadencji VI-VII (a więc okresu C). W okresie B liczba dni obrad w kolejnych latach kadencji raczej rosła, natomiast $\mathrm{w}$ okresie $\mathrm{C}$ - raczej spadała. Liczba posiedzeń w całym badanym czasie była natomiast stabilna, wynosząc w pełnych latach kadencji średnio około 28 i wahając się między 24 a 33.

Co więcej, z analizy wynika, że średnia liczba dni kadencji przypadających na dzień obrad w całym okresie 1989-2015 wahała się dość znacznie - i tu różnica między okresem B i C była jednak największa. W ramach podokresów wahania były znacznie większe w okresie A i B, niż w okresie C. Największe różnice w częstotliwości dni obrad odnotowano między kadencjami I i II, a więc na pograniczu okresu A i B. Największą różnicę w częstotliwości posiedzeń odnotowano natomiast między okresem B i C (w szczególności między kadencjami IV i V). Wydaje się zatem, że jeżeli szukać różnic w badanym okresie, to dotyczą one przede wszystkim okresu kadencji X-IV oraz V-VII. Skrótowo, wyniki te przedstawione zostały w tabeli 4.

Tabela 4

Charakterystyka wskaźników wykorzystania czasu organizacyjnego w dwóch okresach

\begin{tabular}{||l|c|c||}
\hline & AB (kadencje X-IV) & C (kadencje V-VII) \\
\hline Liczba dni obrad & znaczące wahania & spadek \\
\hline Liczba dni obrad w kolejnych latach & raczej wzrost & raczej spadek \\
\hline $\begin{array}{l}\text { Średnia liczba dni kadencji przypadają- } \\
\text { cych na dzień obrad }\end{array}$ & wahania & stabilizacja \\
\hline $\begin{array}{l}\text { Średnia liczba dni kadencji przypadają- } \\
\text { cych na posiedzenie }\end{array}$ & wzrost & spadek \\
\hline $\begin{array}{l}\text { Średnia liczba dni obrad przypadających } \\
\text { na posiedzenie }\end{array}$ & wahania & \\
\hline
\end{tabular}


Przeprowadzona analiza pozwala zatem stwierdzić, że różnice między wspomnianymi okresami są na tyle znaczące, że mogą świadczyć o istnieniu nie trzech, ale dwóch okresów w historii transformacyjnego parlamentu. Przy tym, czas między IV i V kadencją wydaje się tu osiowy. Nie wiadomo również, jak wyraźne będą te różnice, jeżeli podobna analiza przeprowadzona by była po upływie kolejnych kilku kadencji.

Na poziomie organizacyjnym należy rozważyć, co mogła oznaczać zmienna charakterystyka między przywołanymi dwoma okresami. W wyniku analizy nasuwa się wniosek, że od początku transformacji wzrastała liczba dni kadencji przeznaczonych na posiedzenie, która ustabilizowała się pomiędzy kadencjami IV i V. Jednocześnie jednak wzrastała średnia liczba dni przeznaczonych na posiedzenia ogółem. Można to interpretować z jednej strony jako wydłużanie się czasu przeznaczonego na pracę w przestrzeni parlamentu oraz - zwrotnie - wydłużanie czasu dostępnego posłom do pracy pomiędzy posiedzeniami (np. w okręgach).

Czy można zatem wnioskować, że wraz z upływem czasu, system parlamentarny przechodził do innego etapu ewolucji? Czy mogło to się przyczynić do zmiany sposobu działania całości systemu politycznego, dla którego parlament stanowi jeden z kluczowych elementów? W celu odpowiedzi na tak postawione pytania należałoby przeanalizować kolejne kadencje Sejmu. Wówczas możliwe będzie uzyskanie odpowiedniego materiału badawczego. Ponadto, wiedza o wykorzystaniu czasu powinna być wzbogacona o badania nad innymi, wynikającymi ze struktury i funkcji parlamentu wymiarami działania politycznego. Można zatem badać to, jak czas organizacyjny był dzielony na aktywność indywidualną i grupową posłów, np. w procesie legislacyjnym czy kontrolnym. Można również rozszerzyć uzyskane tu wyniki o analizy wykorzystania czasu w Senacie. To właśnie wyniki badań nad czasem wzbogaconych o wspomniane dodatkowe wymiary aktywności parlamentarnej pozwolą uzyskać wnioski dla życia politycznego.

\section{Bibliografia}

Agre P. E. (2002), Real-time politics: The internet and the political process, „The Information Society", vol. 18, nr 5, s. 311-331.

Alonso A. M. (1994), The politics of space, time and substance: State formation, nationalism and ethnicity, „Annual Review of Anthropology”, vol. 23, s. 379-405.

Anderson S. E., Woon J. (2014), Delaying the buck: Timing and strategic advantages in executive-legislative bargaining over appropriations, „Congress \& the Presidency", vol. 41, s. 25-48. 
Blok Z. (2006), Transformacja jako konwersja funkcji wewnatrzsystemowych na przyktadzie Polski, Wydawnictwo Naukowe UAM, Poznań.

Cargill T. F., Hutchinson M. M. (1991), Political business cycles with endogenous election timing: Evidence from Japan, ,The Review of Economics and Statistics", vol. 73, nr (4), s. 733-739, https://doi.org/10.2307/2109416.

Chmaj M. (1996), Sejm , kontraktowy” w transformacji systemu politycznego Rzeczypospolitej Polskiej, Wydawnictwo Uniwersytetu Marii Curie-Skłodowskiej, Lublin.

Collier R. B., Collier D. (1991), Critical junctures and historical legacies, Princeton University Press, Princeton.

Dudzińska A. (2015), System zamknięty. Socjologiczna analiza procesu legislacyjnego, Wydawnictwo Naukowe Scholar, Warszawa.

Easton D. (1979), A systems analysis of political life, The University of Chicago Press, Chicago-London.

Gersen J. E., Posner E. A. (2007), Timing rules and legal institutions, „Harvard Law Review", s. 543-589.

Goetz K. H. (2009), How does the EU tick? Five propositions on political time, „Journal of European Public Policy", vol. 16, nr 2, s. 202-220.

Goetz K. H. (2013), The EU timescape, Routledge.

Hix S., Marsh M. (2011), Second-order effects plus pan-european political swings: An analysis of European Parliament elections across time, „Electoral Studies”, vol. 30, nr 1, s. 4-15.

Huntington S. P. (1991), Democracy's third wave, „Journal of Democracy”, vol. 2, nr 2, s. 12-34.

Kamiński A. (2010), Stracony moment konstytucyjny w pokomunistycznej Polsce: skutki dla jakości rzadzenia dwadzieścia lat później, w: Modernizacja Polski. Struktury, agencje, instytucje, red. W. Morawski, Wydawnictwa Naukowe i Profesjonalne, Warszawa.

Kasianiuk K. (2016), Zespoły poselskie i parlamentarne jako formy samoorganizacji parlamentarzystów. Wyniki polskich badań eksploracyjnych, „Wrocławskie Studia Politologiczne", vol. 20, s. 124-140.

Kayser M. A. (2005), Who surfs, who manipulates? The determinants of opportunistic election timing and electorally motivated economic intervention, „American Political Science Review", vol. 99, nr 1, s. 17-27.

Lamport L. (1998), The part-time parliament, „ACM Transactions on Computer Systems (TOCS)", vol. 16, nr 2, s. 133-169.

Lupia A., Strøm K. (1995), Coalition termination and the strategic timing of parliamentary elections, „American Political Science Review”, vol. 89, nr 3, s. 648-665, https://doi.org/DOI: 10.2307/2082980.

Nalewajko E., Wesołowski W. (2007), Five Terms of the Polish Parliament, 19892005, „,The Journal of Legislative Studies”, vol. 13, nr 1, s. 59-82, https://doi. org/10.1080/13572330601165295. 
Osborne P. (1995), The politics of time, Verso, London.

Rasmussen A., Toshkov D. (2011), The inter-institutional division of power and time allocation in the European Parliament, „West European Politics”, vol. 34, nr 1, s. 71-96.

Sartori G. (1994), Teoria demokracji, tłum. P. Amsterdamski, Wydawnictwo Naukowe PWN, Warszawa.

Schumpeter J. A. (2013), Capitalism, socialism and democracy, Routledge.

Sokołowski J., Poznański P. (2008), Wybrane aspekty funkcjonowania Sejmu w latach 1997-2007, Oficyna Wydawnicza AFM, Kraków.

Toshkov D., Lowery D., Carroll B., Berkhout J. (2013), Timing is everything? Organized interests and the timing of legislative activity, „Interest Groups \& Advocacy", vol. 2, nr 1, s. 48-70.

Uchwała Sejmu Rzeczypospolitej Polskiej z dnia 30 lipca 1992 r. Regulamin Sejmu Rzeczypospolitej Polskiej, M. P. 1992, Nr 26, poz. 185.

Zubek R., Klüver H., Matczak M., Zalasiński T. (2012), Barometr legislacyjny. Analiza przyczyn braku terminowości w realizacji rzqdowych planów legislacyjnych w latach 2008-2011, Domański-Zakrzewski-Palinka, Warszawa.

\section{Time in a democratic parliamentary system. The case of Polish Sejm between 1989-2015}

\section{Summary}

Regardless of the theoretical perspective, the aspect of time is recorded in every study regarding the evolution of political systems. It is of particular importance in the analysis of systems transforming from authoritarian to democratic regimes. This applies to many parliamentary systems, i.e. based primarily on mechanisms of periodic elections to representative bodies. Relatively little attention is paid to the topic of time in Polish political science literature.

The aim of the article is to present the results of research on the use of time in the Polish Sejm in 1989-2015, i.e. in the term of office X-VII. Time was analyzed in the physical and organizational sense. On the basis of official data from the Sejm of the Republic of Poland, the dynamics of the use of time was examined by analyzing the number of meeting days and the length of Sejm sessions. The research results indicate that the characteristic feature of the analyzed period is the changing dynamics of time use in Sejm. In this regard, the fourth (IV) and the fifth term (V) of Sejm seem to be the most important.

Key words: political system, democracy, Polish Sejm, time, systemic transformation 